\title{
The Funeral of Mr. Wang
}

Mr. Wang died of cancer at the Nanjing Municipal Hospital of Chinese Medicine during the wee hours of the morning on December 14, 2014. He was eighty-four years old and had been at the hospital for almost two weeks. Before coming to the hospital, he saw a series of doctors about pain in his legs and hips, but checked into the hospital when the pain increased. About five days before his death, a doctor at the hospital told his younger daughter that a prostate cancer had spread to his bones and become incurable. The news was a bit of a shock to his family, who had imagined that his pain stemmed from some sort of arthritis. The family did not tell Mr. Wang of the prognosis, but he guessed from their demeanor and asked them to contact his middle child, who lived abroad. His treatment consisted primarily of pain relief, though no opiates were used and Mr. Wang often complained of discomfort.

Mr. Wang had two daughters and one son, all of whom were in their fifties at the time of his death. His son (the eldest child) and the younger daughter lived in Nanjing, while the older daughter had emigrated to England. As in many Chinese hospitals, the hospital administered his medicine and checked his vital signs regularly, but did not provide much physical care. It was up to the family to cook his meals, feed him, help him to go to the toilet, wash his body and change his clothes. Mr. Wang needed someone to be in the hospital room twenty-four hours a day, as the pain from the bone cancer prevented him from getting out of bed without help. A cot was set up so whoever was with him could sleep. His wife was too old and frail to provide this help (she rarely ventured outside of their apartment), and much of the burden fell on the younger daughter, with some help coming from the son. It was too much for the second daughter to handle. She had to return to her home to cook meals for her father, and also could not get time off from work every day. So she hired a helper from the countryside, at a cost of 120 yuan per eighteenhour shift. (During the period of research, 1 USD was worth approximately 
6.5 yuan.) The elder daughter flew back to Nanjing in time to see her father before he died, but not in time to be of much practical assistance.

The father died the night after the elder daughter returned. She had stayed with him the previous afternoon and evening, but arrangements had already been made for the helper to spend the night in the room, so Mr. Wang urged his daughter to return to his apartment and spend the night with her mother. "We have already had a good talk; you have been a good daughter to me too; we can have another talk tomorrow morning."

At 5:30 in the morning, the younger daughter received a phone call from the helper. Mr. Wang had passed away sometime that night. He was alive when she checked him at about 1:00 a.m., but when she woke after 5:00 a.m., she discovered that he had stopped breathing. She called in the duty nurse from the hospital, who brought in a doctor. The doctor declared him dead and his body was moved to the hospital morgue (太平间). The helper told the younger daughter that she knew someone who could arrange the funeral (known in Nanjing as a "one-stop dragon" (一条龙) because they arrange the convoluted process from start to finish). The helper said that she could take the daughter to the one-stop dragon shopfront, which was right outside the hospital's rear gate, and the younger daughter agreed to meet her at the hospital. The younger daughter called her husband, her brother, and her mother, who told the middle daughter. The three siblings agreed to meet at the shopfront of the one-stop dragon entrepreneur; the younger daughter texted them the address.

The helper called the one-stop dragon entrepreneur, a Mr. Chen, who, since people die at all hours, took calls twenty-four hours a day and slept in his shop. By 7:00 a.m., all of the siblings were at the shop. Mr. Chen explained that it was traditional to arrange the cremation, farewell meeting, and burial of the cinerary casket on the third day after death, with the day of death counting as the first day. If they needed more time they could do it on the fifth day or the seventh day, but it would be inauspicious to arrange the funeral on the second, fourth, or any even-numbered day after the death. The siblings agreed that they would arrange the funeral for the third day-December 16. Mr. Chen then explained the prices for his services. His base price was 900 yuan, which would include accompanying and directing the family through all of the government procedures necessary after death; setting up a home altar in Mr. Wang's apartment and helping with ritual procedures there; accompanying the family to the state-run crematorium and funeral home and making arrangements there; accompanying the family after the cremation while they took the cinerary casket to the cemetery; directing an interment ritual at the cemetery and arranging a banquet for those who attended the interment ritual. He would advise the family on the proper way of acting for the entire procedure and could also arrange many optional extras, such as musicians to play dirges at appropriate points in the process, religious specialists to perform parts of the ritual if the family were religious, and the purchase of a cemetery plot if the family didn't already have one. 
Because this price was heavily discounted, the family would also need to purchase a cinerary casket (骨灰盒) from Mr. Chen's shop, a set of “longevity clothes" (寿衣, the clothes in which Mr. Wang would be dressed for display in an open casket at his funeral and then cremated), and the "return gifts" which the family would give to those who gave a cash gift to the family during the ritual period. Mr. Chen finally explained that the family would need to prepare about 500 yuan of additional money to give to various people who would assist in the process along the way, and should also be prepared to spend between 5,000 and 10,000 yuan for a basic funeral at the state-run crematorium/funeral home (殡仪馆). The purchase of a graveyard plot could range from 15,000 yuan to well over 200,000 yuan, depending on the cemetery and the size of the plot. The cost of the banquet would depend on the level of food that they offered, the restaurant they chose, and the number of people who were to attend. If they anticipated an extremely large or grandiose funeral, the price would, of course, be much more. After a bit of negotiation, the siblings and $\mathrm{Mr}$. Chen came to the following agreement: they would pay 900 yuan for the basic service, purchase a 2,500-yuan cinerary casket from Mr. Chen's shop (his shop displayed cinerary caskets running from 1,500 yuan to over 10,000 yuan), and buy between twenty and thirty return gifts at a price of 35 yuan per gift. Since their father had already prepared a set of clothes to be dressed in for his funeral (the middle daughter had brought these with her from her parents' apartment), they did not need a set of longevity clothes. In addition, the family had already purchased a cemetery plot. Finally, the family was not particularly religious and did not want any musicians or other ritual specialists. Since they did not anticipate too many people attending the funeral, they would arrange a relatively simple and inexpensive ceremony at the state-run funeral home. They paid Mr. Chen the 3,400 yuan for the cinerary casket and the three days of service in cash, and said that they would pay the money for the return gifts as soon as they determined how many they needed.

Mr. Chen, one of his assistants, the helper, and the three siblings then walked across the street to the hospital morgue, leaving Mr. Chen's shop in the care of another of his assistants. Mr. Chen called the funeral home to arrange for a car to come to pick up the body and transport it to the funeral home, where it would rest in cold storage until the funeral. Mr. Chen also asked the siblings if they wanted to wash the body of their father one last time and then change him into his funerary clothes, or whether they would like to pay one of the attendants at the hospital 200 yuan to do this for them. The middle daughter was quite overcome with grief (she told me that she felt guilty for not having been able to spend more time with her father, and because her father seemed to have waited to see her one last time before dying). She sobbed and insisted on bathing her father's body herself, so Mr. Chen got his assistant to fetch a bucket, a sponge, and a towel so that she could give her father a sponge bath. With the help of her younger sister, the middle sister undressed her father, rolled him from side to side as she sponged him off and dried his body, and then dressed him in his funeral clothes. 
Mr. Wang had been a low level cadre, so he did not want to be remembered in the "Tang dynasty" style of longevity clothes (many of which were for sale in Mr. Chen's shop). Such outfits were decorated with dragons and other symbols of good fortune and reeked of "superstition" in the view of secular communists. So his final outfit, specified in a discussion with his wife before he entered the hospital, was a western suit. But, in accordance with the Nanjing tradition of "five collars and three waistbands" (五领三腰), the outfit had five layers on top and three on the bottom: an undershirt, a long-sleeved thermal shirt, a blue dress shirt, a sweater, and a tweed jacket on top, and underpants, thermal pants, and dark dress trousers on the bottom. As with the number of days to wait after death before conducting a funeral, an "odd" number of layers is specified because an even number suggests "doubling," and it would be inauspicious to suggest a doubling of something like a death. The layering was also important because it prevented the soul from becoming cold in the afterlife. While the daughters were washing and dressing the body, Mr. Chen took the helper aside and paid her a 250-yuan referral fee. The helper then said goodbye to the siblings and left.

The car from the funeral home arrived at the hospital twenty minutes later and four attendants from the hospital carried the body to the hearse. Mr. Chen told the siblings to form a procession to the car, led by the son and in birth order, and asked them to pay the four attendants 50 yuan each for their service. After the hearse left, Mr. Chen asked if they had any photos of the father that could be used for a portrait on the home altar. The younger sister had a photo on her mobile phone that the siblings decided was appropriate. Mr. Chen then suggested that they break into two groups. One would drive to the police station and then the funeral home to do the necessary paperwork. The other would go to the photo shop to have the portrait made from the digital photo and assemble the other materials needed for the home altar. He also told the siblings to think of which friends and relatives they needed to notify of the death. Since the brother had driven there, they decided that the brother and Mr. Chen would drive to the police station, the younger sister and the assistant would go to the photo shop, and the middle sister would return home to accompany their mother.

Mr. Chen and the older brother first walked to an office in the hospital where they settled accounts and obtained the death certificate. Then they drove to the apartment to pick up Mr. Wang's household registration booklet, his identity card (身份证), and the receipts showing that he had purchased a plot in a cemetery. Next they drove to the neighborhood police station, and showed the papers to one of the officers. The police officer removed Mr. Wang from the official (computerized) household register, crossed his name off of the brother's paper version, destroyed Mr. Wang's identity card, and issued the older brother a "certificate of household registration erasure" (户口消灭证). Next, they drove to the Nanjing Crematorium and Funeral Home, which is located at the southern fringes of the urban area, roughly a thirty-five-minute drive from downtown Nanjing. At 
the funeral home, they used the death certificate, the receipts from the cemetery, and the certificate of household registration erasure to obtain two more certificates: a certificate of permission to cremate a body and a certificate of permission to dispose of the ashes of a cremated body (to be used at the cemetery).

After obtaining these certificates, they went to the business counter of the funeral home to arrange the "farewell meeting" (告别会). As the siblings had agreed, the brother selected the most basic (but relatively standard) form of service available. The farewell meeting would be in a small room (large enough for about forty people, and rented for one hour), and the room would be decorated with flowers at the basic level. They would not use a separate room for people to visit the body before the funeral itself (守灵厅). Mr. Wang's body would be lightly preserved (a slight injection of formaldehyde rather than a full embalming; it was winter and the body only needed to last another forty-eight hours), and a low level of make-up would be applied to his face. At the farewell meeting he would be displayed in a basic coffin, in which his body would then be burned. He would be cremated in the standard rather than the upgraded crematory oven (which is "greener," takes a bit less time to cremate the body, more fully turns the bones to ashes, and completely separates the ashes of each body cremated). The fees for the rental of a small room and its decoration, the transport of his body to the funeral home and its storage for two days, the preparation of the body, the master of ceremonies at the farewell meeting, the cremation, and the coffin would come to 6,200 yuan.

The elder brother also gave some basic information about Mr. Wang's career and family to the funeral home workers to use when giving the eulogy at the farewell ceremony. Many of the time slots for farewell meetings on December 16 had already been taken (because Nanjing people like to hold funerals in the morning, funerals start at 6:00 a.m. and go until 10:00 a.m. to allow the funeral and cremation to be finished before noon), but they secured an 8:00 a.m. slot for the small room, followed by a 9:30 a.m. cremation. The brother then paid the 6,200 yuan in full, and obtained a receipt and the name of the room that they had reserved. Mr. Chen and the brother next went to the cemetery where Mr. Wang had purchased a plot, which was another ten minutes' drive away from the city center, south of the funeral home.

There are thirteen public cemeteries and a number of private ones (reserved for people of particular villages) near Nanjing. Six of the cemeteries are located fairly close to the funeral home. All except for the most prestigious (the Garden of Merit, Gong De Yuan 功德园) are located far from the city center. In 2006, Mr. Wang had purchased a plot in one of the less expensive cemeteries. Prices had been rising rapidly, so Mr. Wang secured a plot for himself and his wife (most plots are for couples, with places for two cinerary caskets, though single and family plots are available). After 2012, to prevent "real-estate speculation," greater restrictions were placed on the advanced purchase of cemetery plots. Since 2012, purchasers 
have had to present a death certificate, a certificate from a doctor declaring the person for whom the plot is being purchased is terminally ill, or an identity card showing that the person is over eighty. When Mr. Wang purchased the plot, he tried to pick one with the best geomancy (风水) possible, though he did not pay the graveyard extra money to get advice from a master of geomancy. He selected a site that would get the morning sun and that was as far as possible towards the left hand side (as you faced it) of the section of the cemetery in which it was located. He also selected and paid in advance for the style of tombstone that he wanted.

At the cemetery office, Mr. Chen showed the certificate of permission to dispose of ashes to the registration desk, and announced their intention to bury a cinerary casket on the sixteenth. The manager there suggested that they pay an extra 800 yuan for cemetery staff to conduct a burial ritual at the cemetery, but Mr. Chen told them that he would direct the ritual himself. However, they would still need some workers to seal the grave, and he said that they would conduct their ceremony at about 11:30 a.m. on the sixteenth. Mr. Chen then asked to review the tombstone style and the names and information to be carved on it. The tombstone would have the names of the father and mother, their birthdates, the names of all the children and grandchildren and children-in-law. There were also spaces for the death dates of the mother and father, and they could now give the death date for the latter. It would take a week to do the carving of the tombstone, so it would not have all of the names at the time of the burial, but that didn't matter, Mr. Chen said. They should revisit the grave once a week for forty-nine days after the death (once every seven days for seven times seven days), so there would be plenty of opportunity to check the carving of the stone. Finally, Mr. Chen checked the map of the cemetery to determine the location of the plot, and the brother and Mr. Chen walked to the site to look it over. Everything seemed in order, so they left the cemetery and returned to the parents' home.

By the time they returned to Mr. Wang's apartment, it was already 2:30 p.m. Mr. Chen's assistant had set up the home altar in the living room. At the photo shop, at a cost of 180 yuan, the phone photo headshot had been blown up into a $40 \times 60 \mathrm{~cm}$ framed portrait of Mr. Wang. A space had been cleared in front of one of the living room' walls by temporarily moving some chairs into the spare bedroom. The portrait had been hung high on the wall. Below it was a blanket to which was attached a piece of white cardboard with the character 奠 (meaning "in memorial" or "in sacrifice for our ancestors"). Below the blanket was a low table with three plates of sacrificial food on it (贡品). Two plates had apples, and the third bananas. On each plate was an odd number (five or seven) of pieces of fruit. In addition, there were two candles placed on either end of the table, which were to remain lit the entire time the altar was set up. Mr. Chen further instructed that at least one relative of Mr. Wang, preferably male, should stay up all night for the two nights until the funeral. Relatives could take turns maintaining this vigil, but it was important that someone remained awake to keep Mr. Wang's soul 
company. They were also to leave the doors to the apartment ajar, even though that meant letting in cold air. In front of the table was a pillow for kneeling down and performing kowtows to the portrait of Mr. Wang. In another corner of the living room, the assistant had set up a table with ink brushes and long strips of paper on which he could write calligraphic couplets for those bringing flower wreaths. At the entrance to the apartment, outside of the front door, the assistant hung two black paper lanterns. Finally, a desk with a gift register on it was set up in the adjacent bedroom to record the gifts of anyone who came by and gave an envelope filled with cash.

In the early afternoon, the husband of the younger sister, the wife of the older brother, and her son-the twenty-six-year-old only paternal grandson of Mr. Wang-had come to the apartment. With their help, the mother and the two sisters made a list of all of the people to be notified. These included Mr. Wang's old work unit; the households of Mr. Wang's two brothers and one sister (including those of all their children); the households of Mr. Wang's wife's sister and brother (including those of all of their children); and the households of all of the brothers and sisters of the son-in-law and the daughter-in-law. The daughter-in-law came from a large family with eight siblings, so her relatives amounted to about a quarter of the people to be notified. Because the middle daughter's husband and son were in England, their relatives would not be notified. Though they would not make it to Nanjing in time for the funeral, they did plan to come a few days later to visit the grave with the middle daughter. Finally, the mother asked them to notify the families of three close former friends of Mr. Wang.

The brother, younger sister, and their spouses made the necessary phone calls. Most of the friends and relatives promised to attend the funeral and said that they would visit the home altar either later that evening or on the following day. The family calculated that they would need twenty-two return gifts for the families that would attend the funeral, and that, counting the immediate family members, thirty-four people would attend the funeral and banquet. The number of return gifts needed was determined by counting the number of households who were giving packets of gift money. If a child lived apart from their parents and acted as a financially independent household, then his or her household would give a cash gift and receive a return gift. No one gave a gift as an individual.

They asked Mr. Chen to bring the twenty-two return gifts to the funeral and to arrange a banquet for thirty-four people at a local restaurant for the afternoon after the funeral. They knew the prices at that restaurant and specified that they wanted to order a banquet at a level of 80 yuan per person. Mr. Chen said he would arrange the banquet and tell the cooks which foods were appropriate. In particular, he said, it was traditional to serve stir-fried cabbage and tofu (白菜豆腐) at funerary banquets. The brother paid Mr. Chen the money for the return gifts.

When they contacted the work unit of Mr. Wang, the call was transferred to the head of the workers' union, who expressed his condolences and said that, as 
city regulations mandated, Mr. Wang's family would receive a final payout in the amount of twenty-four times his monthly pension. Since Mr. Wang's pension was 3,900 yuan per month, the payout would be 93,600 yuan. To receive the payout, the family members would have to bring the mother's ID card, the mother's bank account information, the death certificate, and the certificate of household registration erasure to the work unit's pension office.

Mr. Chen then returned to his shop. He told his assistant to remain with the family until 9:30 p.m., and to return the following day from 8:00 a.m. until 6:00 p.m. to write couplets and to assist the family. Mr. Chen would return at 6:00 a.m. on the morning of the funeral and direct the family through it. On the way to his office, Mr. Chen arranged the banquet.

The first official visitor to the household was the son of Mr. Wang's older brother. Mr. Wang's older brother was still alive but too frail to leave the house in winter himself, as was his wife, so this nephew of Mr. Wang was the official representative of that household. He brought a gift of 1,00o yuan in a white envelope and a flower wreath. Mr. Wang's daughter-in-law made a record of the gift in the gift register, listing it as coming from the household of Mr. Wang's older brother. Mr. Chen's assistant inquired about the name of the visitor and his relationship with Mr. Wang and then wrote out a calligraphic stock phrase on white strips of paper: "Magnificent Uncle (father's younger brother) last forever, your nephew, XXXX" (叔叔大人千古, 侄儿XXXX). Mr. Chen's assistant attached the calligraphic strips of paper to the flower wreath and put it in a prominent position in the living room. The assistant then directed the nephew to either bow or use the pillow to kowtow three times to the portrait of Mr. Wang. The nephew performed three kowtows. The assistant then directed Mr. Wang's son to perform three kowtows to thank the nephew. That ended the ritual portion of the visit, but the nephew stayed for about thirty minutes longer to offer his condolences to Mr. Wang's wife and children and to make small talk.

Over the rest of the evening and the following day, representatives of the twenty-two invited households came by to offer their condolences and give gifts. From some households just one person came, but from others couples or even entire nuclear families dropped by. All of them brought envelopes of cash, which ranged from 200 yuan to 1500 yuan. The largest gift was given by the household of Mr. Wang's sister, who were quite well off and had been particularly close to the family. The smaller gifts came from the relatives of the in-laws and a few of Mr. Wang's more distant nephews. Nine of the households also brought flower wreaths, which, with the added calligraphy, were put on display in the living room. Mr. Wang's son, his son-in-law, and his paternal grandson took turns staying up to maintain the night-time vigil. Mr. Wang's wife complained of the cold, but they left the doors open anyway. Mr. Wang's son always performed the return bows and kowtows.

At 6:00 a.m. on the sixteenth, Mr. Chen returned to Mr. Wang's apartment as planned. The three siblings and their spouses and the grandson had either spent 
the night or had come over early in the morning. Mr. Chen brought with him 30 yuan worth of Chinese ten-cent coins. He explained that they needed to throw these out of the car window on the way to the funeral home whenever they crossed a bridge or passed a major intersection to appease the ghost of Mr. Wang. He also brought a red cloth and the cinerary casket that the family had purchased, as well as some spirit money. He had told the family to prepare some food products and liquor to be used as sacrificial offerings in the burial ceremony, and he placed these into a carrying container. He asked the siblings if they wanted to bury any objects (随葬品) with Mr. Wang's ashes. They chose to bring Mr. Wang's electric shaver, glasses, a package of cigarettes, and a cigarette lighter. Mr. Chen also suggested that they bring Mr. Wang's clothes and burn them at the funeral home. Mr. Chen had driven his own car, and Mr. Wang's son and son-in-law had also driven cars that morning. The three siblings, the son's wife, the younger daughter's husband, and the grandson collected the portrait of Mr. Wang and the flower wreaths, Mr. Wang's clothes, and the other items needed for the rituals, and got into the three cars. Because of her health, Mr. Wang's wife did not go to the funeral. On the road, the caravan tossed coins out of the windows whenever they stopped at a major intersection or crossed a bridge. By the time they arrived at the funeral home it was 7:15 a.m. They had to wait until 7:35 for the people using the room before them to finish, but at 7:40 they were able to enter the room they had reserved for the farewell ceremony. At the back of the room was a place for Mr. Wang's open casket. They hung Mr. Wang's portrait on innermost wall of the room and arranged the nine wreaths that relatives had brought to their home around the other flowers decorating the room. The funeral home workers also rearranged the characters on the door frame to the room so that they announced Mr. Wang's funeral instead of the person who came before him. The family members were given black armbands to wear. Outside of the door was a desk for guests to register.

The other guests arrived shortly thereafter. The funeral home worker who registered the guests passed out white flowers and black armbands to each person. The guests milled about outside the farewell meeting room while the family members and the funeral home workers made the final arrangements inside. Mr. Wang's body was brought into the room in an open casket and placed on the platform, near the back wall, with his head towards the west side of the room (the left-hand side of the room from the perspective of someone standing at the door). The immediate family members looked at the body and had a moment to grieve and collect themselves. Outside of the room, Mr. Chen introduced himself to the guests and said that they should arrange themselves into rows of six people, with those who were more closely related to Mr. Wang at the front, and birth order determining the position of those who were equally related. Following this logic, the households arranged themselves in the following manner: at the front were the families of Mr. Wang's siblings, followed by the families of Mr. Wang's wife's 
siblings, and then the siblings of the daughter-in-law, the siblings of the son-in-law, and finally the friends of Mr. Wang. Within each group the families of elder siblings came before the families of younger siblings, though the layout of the room required families to mix together to form rows of six.

The master of ceremonies, a woman employed by the funeral home, told the immediate family members to stand in the front row of the room (closest to Mr. Wang's casket) and called for the doors of the room to be opened so that the other guests could enter and assume their positions. She herself stood behind a lectern positioned at the back right-hand corner of the room, facing the audience of mourners. After everyone had assumed their positions, the master of ceremonies began talking: "We are here today to mourn the passing the venerable Mister Wang (王老先生). Our hearts are full of grief because Mr. Wang was a good man, a respectable cadre who contributed to the building of our nation. He was a good father, husband and grandfather. ..." In all, she spoke for only three minutes and, as had been agreed on beforehand, no other person gave a speech. After her speech, she said, "We will now bow collectively three times to the deceased. Bow once." Everyone bowed. "Bow twice." Everyone bowed again. "Bow a third time." Everyone bowed one more time. She then told the immediate family members to take a step forward, bow three times in front of the coffin, throw their white flowers into the coffin, and walk counter-clockwise around the coffin until they reached the west wall of the room, leaving a space between themselves and the coffin for the other mourners to pass. The two daughters cried quietly while the men stood solemnly. The master of ceremonies then directed each row of mourners to step forward, perform three bows in front of the coffin, throw their white flowers into the coffin, and walk around Mr. Wang's body in a counter-clockwise direction until they reached the line of the immediate family members. When they reached the family members, each row of mourners shook their hands in turn and offered some brief words of condolence. When they finished consoling the immediate family members, they left the room, and the master of ceremonies invited the next row of mourners to step forward. Because there was only one short speech, the entire farewell ceremony took only about twenty minutes.

After leaving the farewell ceremony, the guests went to the parking lot and waited while the immediate family members collected Mr. Wang's portrait, the flower wreaths, and Mr. Wang's clothes. The funeral room workers took Mr. Wang's body to be cremated. With the grandson holding Mr. Wang's portrait, Mr. Chen then led them to a room with a furnace for burning items brought by mourners (separate from the furnaces used to cremate bodies). Mr. Chen directed them to burn Mr. Wang's clothes, the flower wreaths, and some spirit money.

In Chinese cultures, burning is the primary way for mourners to give things to their deceased loved ones. As in many other cultures, it is also possible to bury items with the deceased, but this may only be done once, and, given the size of contemporary burial plots, can only include small items. Foodstuffs are also given 


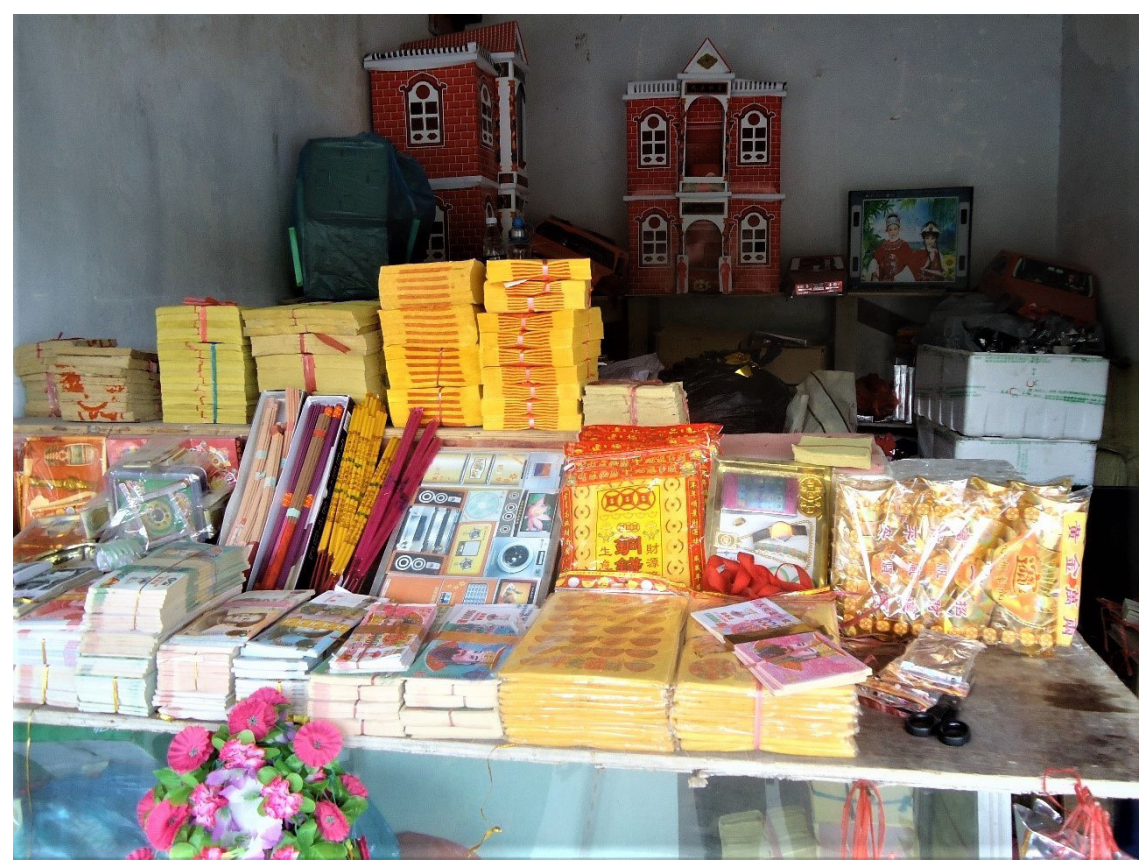

FIGURE 1. Varieties of spirit money. Photo: Andrew B. Kipnis.

to the dead (and to gods) by placing them on altars or on the grave itself. Most of what is burnt, however, are paper replicas of items that might be useful to or give pleasure to the deceased. These can include paper houses, cars, refrigerators, microwave ovens, mahjong sets, and even condoms or beautiful women, but the most common is money. The money is not "real" (the replicas are so fake that no one would consider them counterfeit currencies) and most often take the form of special "spirit" or "purgatory" currencies, but sometimes imitate ancient Chinese forms of money, US dollars, Euros, or other valued currencies, quite often in outlandishly large denominations. ${ }^{1}$

In the case of the deceased's clothes (as well as the flower wreaths), the items burned are real. The logic is partially the same-once burned, the deceased can use or enjoy the items in another world. But another logic also applies, as Mr. Chen explained: some things, if retained by the living, are likely to bring them bad luck. Moreover, retaining the clothes of a deceased person might cause his or her ghost to linger and haunt the house where the clothes are kept. Perhaps as a consequence of such ideas, there are few markets for second-hand clothes in China and few people would ever consider wearing clothes that were once owned by someone who is now deceased.

After the family burned the clothes and other items, Mr. Chen took them to the waiting room of the funeral home's crematorium. They brought Mr. Wang's 
portrait, the cinerary casket purchased from Mr. Chen, and a red cloth Mr. Chen had prepared. At 10:15 a.m., the crematorium room attendant called for Mr. Wang's family to come to a desk where they would receive Mr. Wang's ashes. First the attendant asked for the cinerary casket and the red cloth. Then he showed the plastic bag with Mr. Wang's ashes to the family members. It had a tag with a number that corresponded to Mr. Wang's number in the record book, which the attendant also showed to the family. Next the attendant placed the ashes in the cinerary casket, closed the lid, wrapped the casket in the red cloth and placed it on an altar. The grandson hung Mr. Wang's portrait behind the casket and Mr. Chen instructed the family members to perform three bows to the casket. Finally, four funeral home workers placed the cinerary casket on a palanquin and carried it to Mr. Chen's car. Mr. Chen instructed Mr. Wang's son to give a 20 yuan tip to each of these workers. With the cinerary casket and the portrait safely placed in Mr. Chen's car, they drove to where the other mourners were parked and then, in a procession led by Mr. Chen's car, to the cemetery.

At the cemetery, Mr. Chen checked in at the office and was soon accompanied by one of the graveyard workers. They picked up a pail for burning spirit money. With the grandson holding the portrait at the front of the line, the daughters carrying the plates of sacrificial food, liquor, and the personal items to be buried with Mr. Wang, and the eldest son carrying the cinerary casket wrapped in a red cloth at the back, they walked in a procession to Mr. Wang's gravesite. When they arrived at the gravesite, the underground chamber on the right-hand side of the site (as the mourners faced it) was open. The right-hand side of the site is the "upper" position in Chinese ritual, and, in a nod to patriarchy, is reserved for the man in dual gravesites. A pillow was placed in front of the open chamber. Mr. Chen directed the immediate family members to stand directly in front of the grave, the other mourners to stand in rows behind them, the eldest son to give the cinerary casket to the graveyard worker, and the grandson to place Mr. Wang's portrait in front of the yet to be carved tombstone.

Mr. Chen then began the burial ceremony: "With sadness in our heart, let us collectively wish the venerable Mr. Wang a peaceful journey. Wealth is the backbone, the cycle of life is eternal (九九归一). Grant the descendants a peaceful life. Five coins placed at the four corners [and the center] guarantee wealth to thrive and a peaceful and stable life."

Mr. Chen placed five 1-yuan coins on the bottom of burial chamber. Then he continued: "The filial piety of the sons and daughters is as deep as the ocean. Kneeling I place the beloved." He knelt on the pillow, took the cinerary casket from the worker, and placed it on top of the five coins. Then he placed Mr. Wang's shaver, glasses, cigarette lighter, and cigarettes into the chamber. Finally, he placed seven more coins on top of the casket and said: "The seven starred coins bring wealth to the entire family. Entering the earth is peace (入土为安). Seal the grave." 
Mr. Chen stood up and the graveyard worker placed a lid on the chamber and sealed it with cement, wiped the grave clean, and left.

Mr. Chen then took out the five plates of sacrificial food (rice, meat, tofu, fish, and bok choy) and arranged them on top of the grave. At the center he placed an incense burner with a candle on either side. He lit some incense as well as both of the candles and placed the bucket for burning spirit money next to the pillow. He called up the eldest son and instructed him to first bow three times in front of the grave, to kneel down on the pillow and perform three kowtows, and finally to burn some spirit money in the bucket. Then he instructed the son to walk counterclockwise in a circle around the small section of the cemetery in which Mr. Wang's gravesite was located, and return to the back of the line. Mr. Chen then told the daughters, followed by the grandson, followed by the son-in-law and the daughter-in-law, to do the same. After the immediate descendants had finished, Mr. Chen directed the other mourners to each perform three bows and burn some spirit money and then return to the parking lot. After all of the nonimmediate family members had left, he lit a cigarette and placed it on the grave for Mr. Wang's spirit to enjoy. He then got out the liquor and two small glasses. He filled one glass and placed it on the grave. He called the oldest son forward and filled the other glass and handed it to him. He instructed the son to toast his father, drink the liquor, bow three more times, and burn some more spirit money. He then instructed the grandson and the son-in-law to do the same. Next, he told the two daughters and the daughter-in-law to bow three times each and burn some money without drinking. They burned the rest of the spirit money. Next Mr. Chen addressed the neighboring graves- "You have a new neighbor, please welcome him"-and lit some firecrackers to scare away unwanted ghosts. Finally, Mr. Chen instructed the eldest son to give three graveyard workers, who had been watching the whole affair, 10 yuan each. They would be responsible for keeping the gravesite clean. Mr. Chen then picked up Mr. Wang's portrait and led the immediate family members back to the parking lot. The graveyard workers impatiently took the sacrificial foods and items from Mr. Wang's grave (this was the last morning burial of the day and the workers were eager for lunch), threw them in a trash bag with all of the ashes from the burning money, and cleaned the gravesite.

Near the graveyard parking lot was another furnace. Mr. Chen said that the portrait of Mr. Wang should be burned, and the siblings agreed to dispose of the portrait in this manner. He told all of the mourners to burn their black armbands as well. The mourners then returned to their cars and drove to the exit of the graveyard, where Mr. Chen had arranged one last act. In a metal platform set up on the pavement, Mr. Chen lit a small fire with dried grass. He told all of the mourners to step over the fire. By doing so they could absorb some of the Yang energy from the fire to counter the excesses of Yin that come from spending time at ghastly places like graveyards and funeral homes. 
By the time they finished, it was almost noon. The banquet was arranged for 2:30 p.m. Most of the mourners departed to return to downtown Nanjing and prepare for it. Mr. Chen gave the immediate family members the packets of return gifts, and suggested that they make and drink some hot sugar water after they returned home to further counter the Yin force (气) of the funeral. Finally, he implored them to visit Mr. Wang's grave or at least perform a sacrifice to him at their home on the first seven weekly anniversaries of Mr. Wang's death. On the one hundredth day they should also visit, and after that they could visit on the traditional days for visiting graves in the Chinese ritual calendar, the most important of which is Qing Ming (April 4 or 5). Finally, he told the family members that they should avoid cutting their hair for the forty-nine-day period. Mr. Chen then thanked the Wang family for their business and left. The siblings returned to the mother's apartment.

At the apartment the younger sister prepared some warm sugar water for everyone to drink while the older sister described the funeral to her mother. The mother voiced her approval about most aspects of the ritual, but said that it would have been better to keep Mr. Wang's portrait, as she did not view it as an inauspicious item. She also said that she would like her own funeral to be as simple as possible. The siblings agreed to meet the next day with the mother to settle accounts around the expenses for Mr. Wang's funeral and hospitalization, and the inheritance of his savings and pension payout.

At the banquet, the siblings handed the packages of return gifts to each of the households who had given money during the mourning visits. The packages included a washcloth and some scented soap, which again could be used to wash off the excessive Yin energy generated by the funeral. The three siblings, the son-inlaw and the daughter-in-law, and the twenty-six-year-old paternal grandson all sat at one table. During the banquet, the grandson drank close to a bottle of hard liquor (白酒), mostly just drinking from his own glass rather than toasting his relatives, as etiquette would demand. After he finished drinking he said: "Now my paternal grandfather has passed away. I am the only paternal grandson in this family, the last member of this Wang family line. I am the only hope for family continuity and everything my grandfather owned should be mine." His mother told him that now was not the time to say such things; they could discuss them when the funeral was over. But this would prove to be the opening salvo of an inheritance battle among the siblings, especially between the brother's family and the younger sister's.

The next day the siblings met in the mother's apartment as planned. The daughter-in-law also came, but not the grandson or the son-in-law. Unlike many of his peers, Mr. Wang had written a will, which stated that his money should be divided equally among the three siblings and his wife. This will greatly upset the daughter-in-law, who insisted that her household should inherit everything. She shouted: "Wang X"-her son- "is the only one who can continue the Wang family line and he is not yet married. To find a good wife he will need to have his 
own apartment and significant family resources. Do you want to end the Wang family line?" The younger sister had a stepson who was already married (and had attended the funeral as a related household rather than a direct descendant), while the middle sister's husband and son had still not arrived in Nanjing. The younger sister said, "We all have children, and I am the one who provided the most care for father and who has been doing the most for mother as well. Why should my brother get everything?" The daughter-in-law replied: "Step-children don't count. Is he surnamed Wang? Will his children be surnamed Wang?" Mr. Wang's wife said that he had left a will and that they needed to respect his wishes.

The mother's declaration seemed to settle the matter, but that was only because what they were fighting over now was not really the most important aspect of Mr. Wang's estate. Because he was a former cadre, Mr. Wang had had some health insurance, but still, the hospital costs had eaten away a significant portion of his life savings. What he had left, along with his pension payout, amounted to slightly more than 200,000 yuan. Much more valuable was the decrepit but well-located downtown apartment in which they were now arguing. The siblings thought that it was worth about 1.9 million yuan at that time and that its value would increase significantly every year. After Mr. Wang's death, the apartment belonged to Mr. Wang's wife, but, given her frail health, the real battle among the siblings was over the future inheritance from the mother. The daughter-in-law said: "Just you wait, if anyone tries to deny my son this apartment you will see what I will do." The daughter-in-law also insisted that when they divided the gift money from the funeral, her family should get all of the money given by her relatives, who constituted the greatest portion of the givers. The mother said fine, they could do it that way, but she was obviously upset. The middle daughter also became angry and yelled at her sister-in-law: "Can't you see that you are upsetting my mother, you should stop saying these things and get out of here." The younger sister did some quick calculations which showed that after accounting for the funeral expenses and the final hospital bill, each share would amount to about 53,00o yuan, with the daughter-in-law's household getting about 1500 more because of her relatives' gifts. The brother and younger sister went to Mr. Wang's work unit to get the pension payout wired into Mrs. Wang's account, and then to Mrs. Wang's bank to withdraw the money (with a signed letter from Mrs. Wang); the daughter-in-law left and the middle daughter remained to comfort her mother.

The next day the three siblings met again in the apartment. They gave the middle sister her share in cash; the other shares were already in the respective households' bank accounts. This would be the last time the siblings met together, other than in courts of law. The brother and his household later sued the younger sister to claim rights over the apartment, but the court ruled that the matter could not be resolved until Mr. Wang's wife either passed away intestate or made a final will. Neither of those events has occurred as of this writing. The brother and his household became enemies of the younger sister, and the middle sister sided with her. 


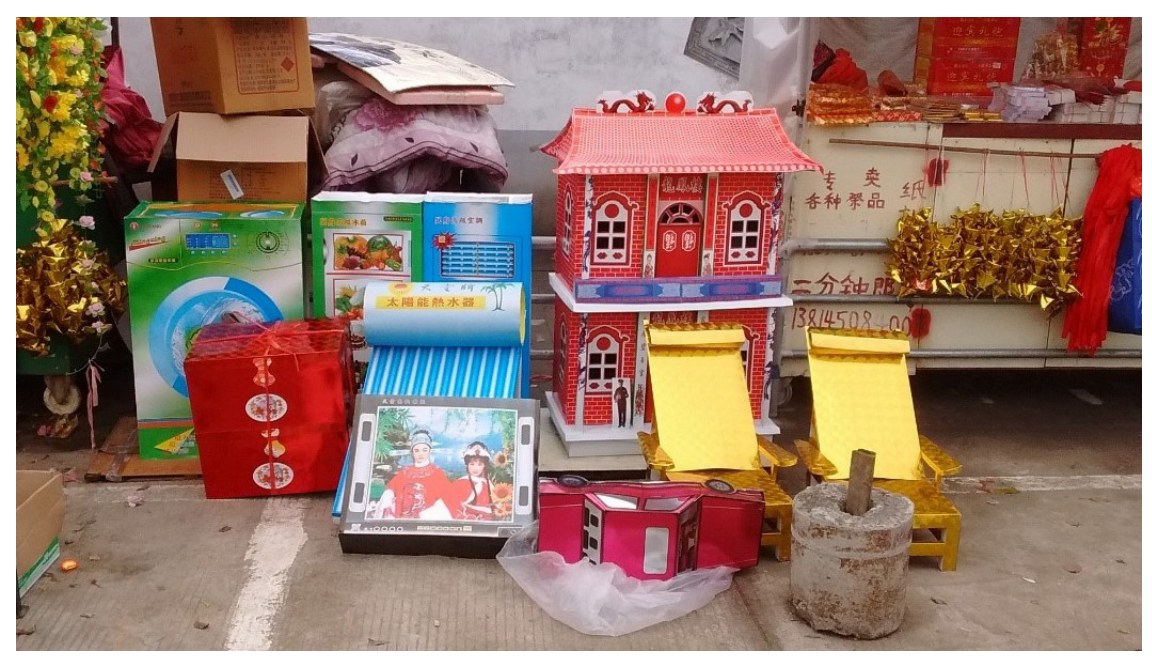

FIGURE 2. Paraphernalia stalls at cemetery. Photo: Andrew B. Kipnis.

The evening after the final meeting of the three siblings, the husband and son of the middle sister arrived from England. They rented a hotel room and the middle sister stayed with them for the following week, though they visited the mother each day. On the seventh day after the death of Mr. Wang, the younger and middle sisters arranged for their households to visit the grave together. The younger sister and her husband picked up the middle sister and her husband and son at their hotel at 9:30 a.m. They drove out to the cemetery. In the parking lot, the two sisters inspected a line of stalls selling spirit money, paper houses, mahjong sets, and furniture items, flowers and other funeral paraphernalia.

The middle sister spent 100 yuan on white chrysanthemums while the younger sister spent 20 yuan on spirit money. They picked up a pail for burning spirit money and walked to the father's grave. The tombstone had been properly carved and painted. On the right-hand side their father's name was engraved vertically, with the engraving of his surname painted red and that of his given names painted black. The surname was red because his family still lived on. Above his name stood the character for "father." His birth and death dates were carved vertically to the right of his name. To the left of the sisters' father's name was the mother's, but her name was entirely in red, as she was still alive. The character for "mother" was above her name; her birthdate was also carved and a space for her death date remained. Above the characters for father and mother was the character 先, which in this context means "elder," "ancestral," or "departed." In smaller characters, on the far left-hand side of the tombstones, carved vertically, were the names of Mr. Wang's children, their spouses, and the grandchildren. Each person was labelled with the appropriate Chinese kinship term, which differentiate children 
from children-in-law and paternal from maternal grandchildren. All of the descendants' names were painted red. The middle sister placed the flowers on the tomb. The younger sister said: "Dad, we have come to see you. Your son-in-law and your grandson (外孙) have come all of the way from England to visit you. Mom is OK. She thinks of you but her health is OK. Don't worry, we will all be fine. Today is the seventh day, we hope you are comfortable. We have brought some money for you." Then she burned some spirit money in the pail. She then told the middle sister's husband and son to perform three bows each and to burn some spirit money in the pail. Finally, she told the middle sister and her own husband to burn some spirit money.

After she finished burning the last of the spirit money the middle sister suddenly began sobbing loudly: "Dad, I should have come and seen you sooner." The younger sister said, "None of us knew he would pass so quickly, there was nothing anyone could do." The middle sister's son and husband put their arms around her and her grief momentarily subsided. They tore the petals from the flowers before they left, so that no one could re-use the flowers and place them on another grave. On the way back to the parking lot they bumped into one of the women who tended the graveyard and they gave her another 10 yuan tip, telling her exactly which grave was their father's and asking her to keep it clean.

The younger sister made two more visits to the grave during the first forty-nine days after death, and also a year after the death and each year in late March, in the weeks before Qing Ming. The middle sister visited the grave whenever she came back to Nanjing. 